\title{
Users' Emotional Experiences in Online Shopping: Effects of Design Components
}

\author{
Esra Özmen ${ }^{1}$ I Ersin Karaman ${ }^{2}$ I Nurcan Alkış Bayhan ${ }^{3}$
}

${ }^{1}$ Dr., Ankara Hacı Bayram Veli University, Ankara/Turkey ORCID: 0000-0001-6661-3473

E-Mail: esra.ozmen@hbv.edu.tr

2 Assoc. Prof., Ankara Hac Bayram Veli University, Ankara/Turkey ORCID: 0000-0002-6075-2779

E-Mail ersin.karaman@hbv.edu.tr

${ }^{3}$ Assist. Prof. Dr., ,Baskent University Ankara/Turkey ORCID: 0000-0002-6393-8907

E-Mail: nurcan.alkis@gmail.com

Corresponding Author: Ersin Karaman

January 2022

Volume:19

Issue: 45

DOI: 10.26466//opusjsr. 1063894

\begin{abstract}
This study aimed to investigate whether users experience an emotional change or not when they focus on design components on e-commerce web pages during shopping process. In this context, a usability study was conducted with participants involved in a real shopping process. In the study, pulse, EEG, Galvanic skin response, eye movements and facial expressions data were collected during shopping process. A total of 32 participants took part in the study. According to the three most focused design components on the web page, "menu and categories", "advertisement" and "search", it was statistically analyzed whether there was a change in the emotions of the participants. As a result, when the participants focused on the "menu and categories" and "advertisement" component, a difference was obtained in the pulse data. In addition, there was a difference in the EEG data compared when they focused on the "menu and categories" and "search" components. Finally, significant differences were also obtained from EEG data when they focused on the "Advertisement" and "Search" components.
\end{abstract}

Key Words: EEG, Pulse, E-Commerce, User Experience, Emotion Change.

Öz

$\mathrm{Bu}$ çalışma, kullanıcıların, e-ticaret web sayfalarında alışveriş sürecinde tasarım bileşenlerine odaklandıklarında duygu değişimi yaşayıp yaşamadıklarım araştırmayı hedeflemiştir. Bu bağlamda, gerçek bir alı̧̧eriş sürecine dâhil olan katılımcilar ile bir kullanılabilirlik çalışması gerçekleştirilmiştir. Çalısmada, alışveriş süresince katılımcıların nabız, EEG, deri iletkenlik, göz hareketleri ve yüz ifadeleri verileri alınmıştır. Gönüllülük temelinde yapılan çalışmada toplamda 32 katılımcı yer almıştır. Web sayfasında yer alan, en çok odaklanılan üç tasarım bileşenine, "menü ve kategoriler", "reklam" ve "arama", göre katılımcıların duygu durumlarında değişiklik olup olmadığı istatiksel olarak analiz edilmiştir. Sonuç olarak katılımcıların "menü ve kategoriler" ile "reklam" bileşenine odaklandıklarında nabız verilerinde farkllik elde edilmiştir. Ayrıca, "menü ve kategoriler" ile "arama" bileşenlerine odaklandıklarında karşılaştırılan EEG verilerinde farklılı tespit edilmiştir. Son olarak "Reklam" ve "Arama" bileşenlerine odaklandıklarındaki EEG verisi karşılaştırıldığında da anlamlı farklılklar elde edilmiştir.

Anahtar Kelimeler: EEG, Nabız, E-Ticaret, Kullanıcı Deneyimi, Duygu Değişimi

Citation:

Özmen, E., Karaman, E. and Alkış Bayhan, N. (2022). Users' emotional experiences in online

shopping: Effects of design components. OPUS- Journal of Society Research, 19(45), 6-18. 


\section{Introduction}

With the improvements in web technologies, websites have become platforms that offer shopping opportunities over the internet, which is called as e-commerce. E-commerce websites operate similar to the traditional shopping environments. Customer reviews are very important for e-commerce websites; since the site serves as similar to traditional shops. Usability studies are conducted to take customers opinions about websites with user experience studies which are performed with various methods and allow the evaluation of user interfaces. Usability tests have been classified according to especially data type in the literature.

In the scope of this study, it is aimed to carry out a user experience study for the evaluation of ecommerce websites. The main research problem of the study is "to identify the changes in the emotional states of the participants when they focus on the design components on e-commerce websites". According to the previous works, it is important to reflect the emotional needs of the users to the e-commerce web page designs (Guo, Cao, Ding, Liu \& Zhang, 2015). To determine positive and negative emotions (such as curiosity and disappointment) in usability studies is important in identifying and eliminating usability problems (Ritonummi, 2020). It is predicted that examining the changes in emotions according to design components will contribute to make inferences for improving website designs. This study got emotion data with more than one method which contributes to the originality of the study.

In order to conduct the user experience study, first of all, an e-commerce website was determined and the necessary permissions were taken from its administration of the website. Emotion data was obtained via EEG, skin conductivity sensors, face coding (with a camera), pulse and eye tracking tools. During the experiment, the participants involved in a real shopping process. The shopping process includes the tasks of finding a product, adding the product to the cart, and making the purchase. During the experiments, EEG, skin conductivity, face coding and pulse data obtained when participants focused on 3 design components ("menu and categories", "advertisement" and "search") and the data was analyzed with statistical methods.

\section{Conceptual Framework}

\section{E-commerce Definition}

E-commerce concept has several definitions in the literature. Simply, it is defined as "purchasing and selling products and services over the internet" (Jewels \& Timbrell, 2001). Similarly, e-commerce can be referred as making business relations, communication between producers and consumers via a website (Laudon \& Traver, 2011). In another definition conducted by Nissen (1997), it is defined as "a process flow related to a commercial relationship or transaction, including activities such as purchasing, marketing, sales and customer support". Based on these definitions, it is clear that e-commerce does not refer to only buying and selling transactions, but also has other dimensions.

Although the foundations of e-commerce date back to the 1980s, shopping over internet and ecommerce applications have started with the use of World Wide Web (www). Especially the foundation of Amazon can be shown among the first important examples of e-commerce. Many factors have influenced the development of ecommerce over the years. In addition to technological developments, factors such as focusing on the customer and improving customer relations, consumer preferences, organizational changes, and easier comparison of products over the internet have also contributed to the development of e-commerce (Coşkun Karadağ, 2005; Erserim, 2019).

E-commerce has various advantages and disadvantages. While product development, testing, providing customer support, and especially quick return to customers are seen as advantages (Erbaşlar \& Dokur, 2008), financial problems and legal regulations are seen as disadvantages. Data protection is one of its biggest disadvantages, especially in terms of cost and changing requirements. 


\section{E-commerce Website}

In e-commerce, the shopping process is carried out as virtual transactions over the e-commerce website or other interfaces. While traditional consumers are affected from store design, colors, sound, and light, consumers in the virtual environment are affected from interface design and appropriate navigation environment on the ecommerce web page (Koufaris, 2002). This comparison has been placed literature, and the website design and its content has been seen as equivalent to the physical store environment. Lohse and Spiller (1998) has mentioned these similarities with various pairings. According to them, when a traditional store is compared to an ecommerce website, the sales representative in a store is equivalent to the search function, product descriptions and online support service of an ecommerce website; the traditional store window is equivalent to the home page of the website and the hierarchical structure of the website is equivalent to the store floors. Similarly, the number of people visiting the store is equal to the number of people visiting the website.

E-commerce website designs and ease of use are important for businesses that carry out their commercial activities in the virtual environment for not to lose their customers, which are their most valuable asset. The design of a customer-focused website is important, because poorly designed websites result in reduced profits to for online businesses (Nielsen, 2002). For an e-commerce website to be successful, it must be visually well designed, considering color factors and placing design components. The customer should be able to easily access the product they are looking for and make product comparisons when necessary. However, there are some measurement and test methods to determine to what extent these suggestions can be fulfilled. Such methods are frequently used especially in usability studies.

\section{User Experience and User-based Testing}

User experience means knowledge gained from repeated efforts. It occurs when the user interacts with the web environment. User experience consists of products, system and interface. The experience should be observable and measurable (Tullis ve Albert, 2013). In user experience, each behavior and action taken is discussed in detail and user expectations are tried to be determined. We can express the shopping process on an ecommerce site as an example of user experience. Shopping from an e-commerce page is done by performing similar transactions each time and creates similar experiences. The user comes to the e-commerce site, finds the desired product (sometimes by using a search engine or browsing a category), fills in the address and credit card information fields on the payment page, and the ecommerce site confirms that the product will be sent to the user. It creates a series of small and large decisions experience about how the e-commerce website looks, how it guides the user, and what it allows to use to take action. In user experience studies, the focused subject, experimental process, sample group, collected data and obtained results are all real. Therefore, these studies are very important because they are completely based on the phenomenon of reality.

User experience is based on visual design, knowledge architecture, design, usability, research and content strategy. The requirements of user experience are presented in Figure 1 as 4 items (Basaran, 2014). 


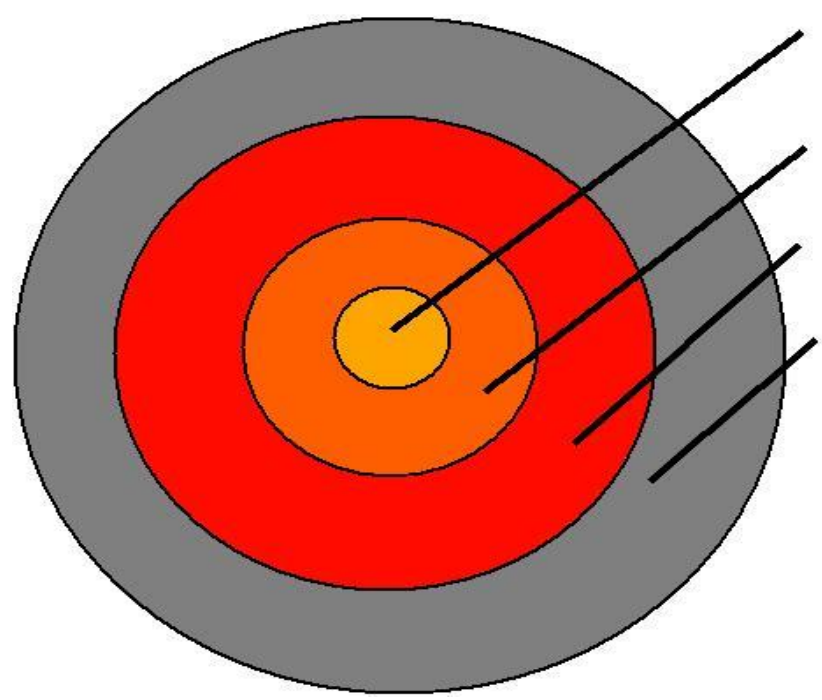

Usefulness: the main purpose of the user experience is to

meet the needs and provide benefits

Usability: the product should be used easily.

Desirability: the design should be trustful.

Brand experience: it should contribute to the branding process

Figure 1. The requirements of user experience

In user experience, various tools and software are used to conduct user-based tests. In the scope of this study, the following techniques were used: eye tracking, brain waves tracking, controlling pulse level, measuring skin conductivity level and facial action coding system. These tests are summarized in Table 1.

Table 1. User-based Tests

\begin{tabular}{|c|c|}
\hline Technique & Description \\
\hline Eye tracking & $\begin{array}{l}\text { Eye tracking technique is one of the mostly used methods in usability studies. It provides data on which points the users } \\
\text { look at while interacting with the tool/interface, how long they look at, and in which trajectory they navigate (Nakatani } \\
\text { ve Pollatsek, 2004). Eye tracking can be used in many areas such as the design of web pages, visual evaluation, mental } \\
\text { processes, action sequences, speech, perception, advertising and shopping (Baş ve Tüzün, 2014). }\end{array}$ \\
\hline Brain waves tracking & $\begin{array}{l}\text { "Electroencephalography" (EEG) is the method to measure electrical activity in the brain. It emerged between } 1925 \text { and } \\
\text { 1930. In the tests performed with EEG, an electrode cap placed on the scalp of the user or earphone are used for } \\
\text { measurement of brain waves. After the experiment process ended, data is obtained by measuring the signals. Lastly, } \\
\text { data is analyzed, interpreted and estimated (Sadedil ve Uraltaş, 2018). }\end{array}$ \\
\hline Pulse level tracking & $\begin{array}{l}\text { Pulse (heart rate) is the value which is used to express how many times the heart beats in a minute. It can be simply } \\
\text { measured with the help of fingers and a watch. The pulse is affected by several factors such as exercise, anxiety, } \\
\text { excitement, fear, and body temperature. Resting pulse is measured while sitting or lying down calmly. The normal pulse } \\
\text { for anyone over the age of } 10 \text { is between } 60 \text { and } 100 \text { beats per minute (bpm) (Medical Academy). }\end{array}$ \\
\hline Measuring skin conductivity level & $\begin{array}{l}\text { The galvanic skin conductivity (GSR), is also known as the electrodermal response (EDR), psychogalvanic reflex (PGR). } \\
\text { GSR can be used to measure the reactions of the skin to the pleasurable and stressful effects by following the changes in } \\
\text { the moisture content of the skin, including palms and fingertips. GSR data are affected by conditions such as arousal, } \\
\text { stress level, deep breathing, and question answering (Grimnes, 1982; Tayfun \& Öçlü, 2015). }\end{array}$ \\
\hline Facial action coding system & $\begin{array}{l}\text { Facial action coding system (FACS) detects the neutral, positive and negative emotion values from } 23 \text { muscle groups on } \\
\text { the face in various emotion types such as sadness, fear, joy, stress, surprise and reveals the specific emotions of the user. } \\
\text { Emotions are evaluated in real time; the head and eye movements are tried to be interpreted together with facial } \\
\text { activities, and each movement has a numerical equivalent (Farnsworth, 2019). A video camera is used in the } \\
\text { measurement, and then, during the analysis phase, these recordings are divided into smaller pieces to capture instant } \\
\text { facial expressions. The technique of identifying facial expressions is often used in advertising testing and movie trailers } \\
\text { testing. }\end{array}$ \\
\hline
\end{tabular}

\section{E-commerce User Experience Studies in the Literature}

There are studies conducted with different user tests in the literature (Yadava et al., 2017; Çakar et al., 2017; Destari et al., 2020). For example, in a study that used EEG signals in neuromarketing, it was discussed whether consumers like the products or not. As a result of this study, a framework for predicting the user's choice preference, developing a market strategy and predicting market success is presented. Also, this study suggested that using eye tracking with EEG will provide more realistic and consistent parameters (Yadava et al., 2017). In another study conducted by Coşkun and Yücel (2021), the 
perceptions of the participants towards ecommerce websites were evaluated by using EEG method. In their study, they mentioned the elements that should be paid attention during ecommerce website design as menu, simple appearance, text, site color and accessibility.

In another study, Çakar et al. (2017) discussed users' first product search processes of on ecommerce sites and conducted a user experience study with male participants using neurometric and biometric research methods. In that study, search experience, use of category menu, use of filters, sorting and product listing processes are highlighted. User are affected negatively from home page navigation, search button, filtering, scrolling up and down the page components. They stated that making improvements for these problematic elements will increase the usability level of the page. In addition, the participants were disturbed from some issues such as the filtering menu was not clear and the relevant buttons could not be found easily. They suggested to conduct multimodal studies in the field of usability by using traditional and neuroscientific methods together to make more clear interpretations.

Oliveira, Afonso, and Pinto (2020) on the other hand, emphasized that home page of websites should be the primary target for improvements in usability and accessibility, because home page of websites is the entry point for the user. They also stated that the continuous improvement of websites improves user experience and reduces the digital divide that people could experience.

Eye tracking method is widely used as a research method in e-commerce user experience studies. With the eye tracking method, it is possible to access the information "which components were viewed more during a certain task". In this way, it can be determined which components are interacted more on the page (Wong, Bartels \& Chrobot, 2014). In a study conducted by Dospinescu and Parcă-Robu (2017) with eye-tracking method in the field of ecommerce, it was revealed that the efficiency and effectiveness of pages with high interaction will be better than others.
Emotional factors are one of the topics covered in user experience research. The emotional needs of the users during the experience have also become a part of the user experience studies. For emotion evaluation in user experience, emotions after use or emotions before use can be considered (Hassenzahl \& Tractinsky, 2006; Ritonummi,2020). Destari et al. (2020) revealed that the quality of the website positively affects the shopping feelings and the customers are affected by the attractive designs and so their shopping behaviors are triggered. In another study, emotional experiences during online shopping were discussed in 3 different dimensions: subjective emotional evaluations, eye movements and physiological responses (Guo, Cao, Ding, Liu \& Zhang, 2015). These dimensions were compared over the shopping experience on two different websites. According to the results obtained from the study, there was no difference in physiological responses (GSR, RSP and SKT) while shopping from different websites. However, significant differences were obtained in subjective emotional evaluations and some indicators of eye movements. It is important that the emotional needs of the users should be reflected to designs, but it is recommended to use multimodal measurement methods since emotions are difficult to measure.

There are different factors that affect website users such as complexity, usefulness and content. Website design is one these factors. Website design should be aesthetic, which increases the effectiveness of the website. Therefore, the quality of the website also increases (Clarke \& Hattingh, 2020). It has been revealed that different design components affect users on e-commerce web pages. Safavi (2009) stated in their study that personalization, registration and $\log$ out, information presentation, shopping cart and payment system components are necessary components for the usability of e-commerce websites.

\section{Methodology}

Aim and Scope of the Study 
The aim of this study is to examine the changes in the emotional states of the users while focusing on design elements in e-commerce websites. The following research question was tried to be answered: "Does the e-commerce interface design have an effect on the user's emotions change during shopping process?". To answer this research question, user-based tests were applied within the scope of the components used in the ecommerce page interface design. During the test, eye tracking device, EEG, pulse monitor, GSR and a high-resolution camera for facial expressions were used. The pulse level, skin conductivity level, facial expressions and variability in brain waves were analyzed when the users focused on the design components.

\section{Population and Sample Group}

The population of the study consists of customers who shop from e-commerce sites using the web interface. The sample group of the study was selected with the maximum variation sampling method, which is one of the purposive sampling methods.

Two participants were excluded from the analysis due to the problems experienced during data collection process. A total of 32 participants took part in the study and their data was analyzed.

\section{Data Collection Tools}

Various data collection tools were used in the study. First of all, EEG was used to measure the brain waves of the participants and a pulse measurement device was used to take the heart rate values per second. An eye tracker was used to monitor eye movements, a camera was used to interpret facial expressions, GSR was used to measure skin conductivity and emotion changes, and screen recording was used to follow the tasks. The data as taken from all data collection tools on a per second basis. The devices used and their details are presented in Table 2.

Table 2. Data Collection Tools

\begin{tabular}{ll}
\hline Data collection tool & Details \\
\hline EEG & $\begin{array}{l}\text { NeuroSky MindWave Mobile device was used to measure brain waves. The brain waves of Delta, Theta, Alpha, High } \\
\text { Alpha, Low Beta, High Beta, Low Gamma and High Gamma were measured every second during the shopping period } \\
\text { of the participants on the e-commerce website with sensors. Delta brain waves were excluded from evaluation since they } \\
\text { are meaningful in deep sleep, unconscious and isolated sleep from the outside world. In addition, theta and alpha wave } \\
\text { measurements, which are significant in very deep relaxation and deep hypnosis states, were not included in the analysis } \\
\text { too. In this context, Beta and Gamma waves were used in further analysis. }\end{array}$ \\
\hline Pulse Measurement Device & $\begin{array}{l}\text { The Polar OH1 Pulse Measurement device, which provides heart rate monitoring through optical detectors, was used to } \\
\text { obtain the pulse data of the participants. Polar OH1 systematically monitors heart rate by making a very precise results } \\
\text { thanks to its high-quality 6-LED optical heart rate measurement. Pulse data was recorded per second during the } \\
\text { shopping process. }\end{array}$ \\
\hline Eye Tracker & $\begin{array}{l}\text { SMI Red250 Eye Tracking device was used to determine which design component the users focused on during the } \\
\text { shopping process on the site. }\end{array}$ \\
\hline Skin Conductivity Sensor & $\begin{array}{l}\text { GSR Skin Conductivity sensor was used to measure the emotions occurring in the sympathetic nervous system of the } \\
\text { participants during the shopping process with the help of the changes in the skin conductivity level. When evaluating } \\
\text { the data obtained from the sensor, a high skin conductivity data means that the emotional state of the participant is } \\
\text { normal, and a low level of data means that there is a change/difference in the participant's emotional state. }\end{array}$ \\
\hline
\end{tabular}

\section{Data Collection Process}

An e-commerce site has been determined by getting the necessary permissions. In the experiment, participants were asked to complete a real shopping process. To participate in the study was totally voluntary. The shopping process in the experiment included the tasks of finding a product, adding the product to the cart, and making the purchase. Demographic information was obtained from the participants before starting the experiment. After the calibration of the data collection devices was completed, the participants started the shopping process. When the shopping process was completed, the data collection process ended with the recording of the experiment and the termination of all the devices used.

\section{Data Analysis}

Eye movement tracking device, EEG, pulse monitor tool, GSR and camera were used in the study. First, the data obtained from these devices were put under a single form for each participant. 
For eye movements, screen recordings and data obtained by SMI Red 250 Eye Tracking device were reviewed. BeGaze 3.7 software was used in the analysis of eye tracking data. Eye movements were labeled on a per second basis, and it was revealed that which components were focused by each participant for every second.

Pulse data collected with the Polar OH1 heart rate monitor was taken on a per second basis and edited by matching with the shopping process. Brain waves were obtained from EEG data. The meaningless waves at interaction process were excluded from the dataset. Before analyzing EEG data, outliers were calculated and determined. Outlier calculation method was determined by examining previous studies on EEG data. Afterwards, GSR data was matched with other data types and normalization was employed. MATLAB was used to get photographs per second from the video of each participant obtained, which was obtained with a high-resolution camera. Emotion identification for each of the photos (30523 photos) obtained on a per-second basis was made with the help of Face++ API. At the stage of defining emotions from photographs, participants were classified into seven different emotions types as nervous, anxious, fearful, neutral, confused, happy and sad.

During the entire shopping process, the data tagged on a per-second basis was first arranged with the help of an electronic spreadsheet (Microsoft Excel) and then transferred to a database management system (Microsoft Access) in order to make queries. The necessary data for emotion change analysis were taken from the database with queries.

Özmen, Karaman, and Alkış (2021) distinguished each design component on the ecommerce page with task-based coding and expressed the frequency of focusing on design components. The five mostly focused design components presented at their works are "menu and categories", "advertisement", "search", "log in" and "information bar". Among these design components, "menu and categories", "advertisement" and "search" design components, which are directly related to the shopping process, are taken into consideration within the scope of this study. Emotion changes were analyzed for these design components via IBM SPSS Statistics 25 software. Normally distributed data was analyzed with Independent Sample T-test, which is used to analyze the difference between design components pairs for each data types of emotions changes. Mann Whitney $U$ test was employed for nonnormal distributed data (Kalaycl, 2014).

\section{Reliability and Validity}

The validity of the study was established on the basis of explaining the data collection tools and processes, determining the assumptions and limitations, and founding the sample selection on the literature (Brinberg \& McGrath, 1985; Merriam, 1998). Describing the experimental process, explaining the role of the researcher, conveying the method selection requirement, and taking the participant's consent are also among the validity measures of the study (McMillan \& Schumacher, 2010; Büyüköztürk et al., 2014). On the other hand, taking expert opinions and preventing data loss by recording all data constitute the reliability measures of the study (Topu et al., 2013; Balat et al., 2019). Collecting data by making a pilot study before the main experiments and trying to eliminate the deficiencies of the experiment process is another reliability measure (Lancaster, Dodd \& Williamson, 2004). While it is sufficient to have five participants in a usability research and user experience study, 32 participants were involved in the study, which is also important in terms of validity and reliability of the current study (Nielsen, 1993). In addition, the calibration value of the eye tracker is less than 0.5 in both eyes during the calibration phase, and the simultaneous use of data collection tools at all stages of the experimental process are among the other reliability measures of the study.

\section{The Role of the Researchers}

In the study, the researchers undertook the tasks of designing and implementing the experiment process, accessing data collection tools, 
communicating with the participants, and collecting data. After the data was collected, the organization, analysis and reporting of the data were also carried out by the researchers of the study.

\section{Ethical Clearance}

Scientific ethical rules were followed during the whole study. In this context, permission was obtained from Atatürk University Social and Human Sciences Ethics Committee to carry out the experiment process with human participants. Evaluation permission was obtained from the administration of the e-commerce site discussed within the scope of the study. In order to use the SMI Red250 eye tracking device, necessary permissions were obtained from Atatürk University Open Education Faculty. A consent form was signed by the participants before the experiment. Also, consent was obtained from the parents of the participants who are under the age of 18 in the study. In addition to these, the data were obtained through real experiments and were not shared with third parties or institutions other than the researchers.

\section{Findings}

First, the findings regarding the demographic information of the participants were presented. A total number of 32 participants took part in the study. The descriptive statistics of the participants, who are between the ages of 16-49, are given in Table 3.

Table 3. Participants' demographic information

\begin{tabular}{llll}
\hline $\begin{array}{l}\text { Demographic } \\
\text { information }\end{array}$ & Groups & N & \% \\
\hline Gender & Female & 16 & 50.0 \\
& Male & 16 & 50.0 \\
\hline \multirow{4}{*}{ Education level } & High school & 12 & 37.5 \\
& Associate degree & 3 & 9.4 \\
& Graduate & 9 & 28.1 \\
& Post graduate & 2 & 6.3 \\
& Doctorate & 6 & 18.8 \\
\hline
\end{tabular}

In order to analyze whether there was a change in the emotions of the participants or not, the heart rate, GSR, EEG and FACS data were obtained during the e-commerce shopping process when they focus on "menu and categories", "advertisement" and "search" design elements. First, all data types were normalized, and their normal distributions and equality of variances were tested in order to determine the applicability of parametric or non-parametric tests. The normality test for all the data handled according to the design elements is presented in Table 4.

Table 4. Normality Findings according to Design Components.

\begin{tabular}{|c|c|c|c|c|c|c|}
\hline \multirow{2}{*}{ Data type } & \multirow{2}{*}{ Design component } & \multicolumn{3}{|c|}{ Kolmogorov-Smirnov } & \multicolumn{2}{|c|}{ Shapiro-Wilk } \\
\hline & & Statistic & df & Sig. & Statis & df Sig. \\
\hline & Menu and Categories & ,098 & 31 & $200^{*}$ & ,972 & 31,583 \\
\hline \multirow[t]{3}{*}{ Pulse } & Advertisement & 133 & 28 & ,200* & ,972 & 28,638 \\
\hline & Search & ,098 & 27 & ,200* &, 953 & 27,255 \\
\hline & Menu and Categories & ,089 & 31 & ,200* & ,977 & 31,722 \\
\hline \multirow[t]{3}{*}{ GSR } & Advertisement & ,117 & 28 & ,200* & 961 & 28,367 \\
\hline & Search &, 071 & 27 & ,200* &, 980 & 27,865 \\
\hline & Menu and Categories & 233 & 31 & ,000 & 760 & 31,000 \\
\hline \multirow[t]{3}{*}{ LowBeta } & Advertisement & ,178 & 28 &, 024 &, 808 & 28,000 \\
\hline & Search & ,356 & 27 &, 000 & 676 & 27,000 \\
\hline & Menu and Categories & 303 & 31 & ,000 & 565 & 31,000 \\
\hline \multirow[t]{3}{*}{ HighBeta } & Advertisement & 243 & 28 & ,000 & 788 & 28,000 \\
\hline & Search & ,326 & 27 &, 000 &, 587 & 27,000 \\
\hline & Menu and Categories & 283 & 31 & ,000 & 800 & 31,000 \\
\hline \multirow[t]{3}{*}{ LowGama } & Advertisement & 238 & 28 &, 000 &, 867 & 28,002 \\
\hline & Search &, 274 & 27 &, 000 & ,794 & 27,000 \\
\hline & Menu and Categories & 110 & 31 & ,200* & 896 & 31,006 \\
\hline \multirow[t]{3}{*}{ HighGama } & a Advertisement & 127 & 28 & $200^{*}$ & 968 & 28,536 \\
\hline & Search & ,106 & 27 & ,200* & ,966 & 27,511 \\
\hline & Menu and Categories & 208 & 31 & ,002 & 838 & 31,000 \\
\hline \multirow[t]{2}{*}{ FACS } & Advertisement & 193 & 28 & ,005 &, 866 & 28,001 \\
\hline & Search & 184 & 27 & ,009 & ,761 & 27,000 \\
\hline
\end{tabular}

When Table 4 is examined, since the number of participants is 32, Kolmogorov-Smirnov test was taken into consideration for the normality of the variable. Looking at the significance value column (Sig.), data groups greater than 0.05 showed normal distribution. Based on this result, Pulse, GSR and HighGama data groups are normally distributed. The results of Levene's Test conducted to find the homogeneity of variances of normally distributed data types are presented in Table 5. 
Table 5. Levene's Test Results for Pulse, GSR and HighGama

\begin{tabular}{llrl}
\hline Data type & Design component & F & \multicolumn{1}{l}{ Sig. } \\
\hline \multirow{3}{*}{ Pulse } & Menu and Categories - Advertisement & 1,647 & 0,204 \\
& Menu and Categories - Search & 1,545 & 0,219 \\
& Advertisement - Search & 0,001 & 0,981 \\
\hline \multirow{3}{*}{ GSR } & Menu and Categories - Advertisement 3,279 & 0,075 \\
& Menu and Categories - Search & 1,082 & 0,303 \\
& Advertisement - Search & 0,399 & 0,530 \\
\hline \multirow{3}{*}{ HighGama } & Menu and Categories - Advertisement & 0,484 & 0,489 \\
& Menu and Categories - Search & 0,144 & 0,705 \\
& Advertisement -Search & 0,159 & 0,692 \\
\hline
\end{tabular}

When the results of Levene's test were examined, it was determined that the variances of the Pulse and HighGama variables were assumed equal $(p>0.05)$. Based on this result, parametric tests were applied for Pulse, GSR and HighGama data groups and non-parametric tests were applied for other data groups. Whether there is a difference between the participants' Pulse, GSR and HighGama data or not was examined with Independent Samples t-test. The results are given in Table 6.

Table 6. Pulse, GSR and HighGama Mean Differences According to Design Components

\begin{tabular}{|c|c|c|c|c|c|c|}
\hline Data type & Design component $\mathrm{N}$ & $X$ & sd & $t$ & df & $\mathrm{p}$ \\
\hline \multirow{6}{*}{ Pulse } & Menu and Categories & 0,48 & 0,146 & \multirow{2}{*}{$-2,756$} & \multirow{6}{*}{30} & \multirow{2}{*}{0,008} \\
\hline & Advertisement & 0,59 & 0,166 & & & \\
\hline & Menu and Categories & 0,48 & 0,146 & \multirow{2}{*}{$-2,504$} & & \multirow{2}{*}{0,01} \\
\hline & Search & 0,58 & 0,172 & & & \\
\hline & Advertisement & 0,59 & 0,166 & \multirow{2}{*}{0,192} & & \multirow{2}{*}{0,848} \\
\hline & Search & 0,58 & 0,172 & & & \\
\hline \multirow{6}{*}{ GSR } & Menu and Categories & 0,48 & 0,205 & \multirow{2}{*}{0,064} & & \multirow{2}{*}{0,949} \\
\hline & Advertisement & 0,47 & 0,265 & & & \\
\hline & Menu and Categories 192 & 0,48 & 0,205 & \multirow{2}{*}{$-0,276$} & \multirow{2}{*}{30} & \multirow{2}{*}{0,784} \\
\hline & Search & 0,49 & 0,251 & & & \\
\hline & Advertisement & 0,47 & 0,265 & \multirow{2}{*}{$-0,294$} & & \multirow{2}{*}{0,770} \\
\hline & Search & 0,49 & 0,250 & & & \\
\hline \multirow{6}{*}{ HighGama } & Menu and Categories & 0,55 & 0,166 & \multirow{2}{*}{0,432} & & \multirow{2}{*}{0,667} \\
\hline & Advertisement & 0,53 & 0,195 & & & \\
\hline & Menu and Categories & 0,55 & 0,166 & \multirow{2}{*}{$-0,505$} & \multirow{2}{*}{30} & \multirow{2}{*}{0,616} \\
\hline & Search & 0,57 & 0,165 & & & \\
\hline & Advertisement & 0,53 & 0,195 & \multirow{2}{*}{$-0,894$} & & \multirow{2}{*}{0,375} \\
\hline & Search & 0,57 & 0,165 & & & \\
\hline
\end{tabular}

When Table 6 is examined, according to the independent sample t-test results, a statistically significant difference was found [t (30) $=-2.756$, $\mathrm{p}<0.05$ ] between the Pulse mean of the "Menu and Categories" design element $(X=0.48)$ and the Pulse mean of "Advertisement" design element $(X=0.59)$. In addition, a statistically significant difference was found [ $\mathrm{t}(30)=-2.504, \mathrm{p}<0.05]$ between the Pulse mean of the "Menu and categories" design element $(X=0.48)$ and the Pulse mean of "Search" design element $(X=0.58)$. On the other hand, there was no statistically significant difference [t (30) $=0.192$, $\mathrm{p}>0.05$ ] between the "Advertisement" design element's Pulse data mean $(X=0.59)$ and the Search design element's Pulse data mean $(X=0.58)$. No statistically significant results were observed in the analysis of the mean of HighGama and GSR data according to design elements ( $p>0.05)$.

Based on the normality analysis results (Table $4)$, since the significance values of LowBeta, HighBeta, LowGama and FACS data were less than 0.05 , they were not normally distributed. For this reason, the Mann Whitney U Test, which is one of the non-parametric statistical tests, was used to examine whether the difference between the means of LowBeta, HighBeta, LowGama and FACS according to design elements is significant or not (Table 7).

Table 7. The Differences Between the Mean Ranks of the Non-Normal Distributed Data of the Participants According to Design Elements

\begin{tabular}{|c|c|c|c|c|c|c|c|}
\hline Data type & $\begin{array}{l}\text { Design } \\
\text { component }\end{array}$ & $\mathbf{N}$ & Mean Rank & $\begin{array}{l}\text { Sum } \\
\text { Rank }\end{array}$ & $\mathbf{U}$ & $\mathbf{Z}$ & $\mathrm{p}$ \\
\hline \multirow{6}{*}{ LowBeta } & $\begin{array}{l}\text { Menu and } \\
\text { Categories }\end{array}$ & & 36,16 & 1157 & \multirow[t]{2}{*}{395} & \multirow[t]{2}{*}{$-1,6$} & \multirow[t]{2}{*}{0,11} \\
\hline & Advertisement & & 28,84 & 923 & & & \\
\hline & $\begin{array}{l}\text { Menu and } \\
\text { Categories }\end{array}$ & 192 & 28,67 & 917,5 & \multirow[t]{2}{*}{389,5} & \multirow[t]{2}{*}{$-1,8$} & \multirow[t]{2}{*}{0,08} \\
\hline & Search & & 36,33 & 1162,5 & & & \\
\hline & Advertisement & & 26,44 & 846 & \multirow{2}{*}{318} & \multirow{2}{*}{$-2,8$} & \multirow{2}{*}{0,006} \\
\hline & Search & & 38,56 & 1234 & & & \\
\hline \multirow{6}{*}{ HighBeta } & $\begin{array}{l}\text { Menu and } \\
\text { Categories }\end{array}$ & & 33,97 & 1087 & \multirow[t]{2}{*}{465} & \multirow[t]{2}{*}{$-0,7$} & \multirow[t]{2}{*}{0,51} \\
\hline & Advertisement & & 31,03 & 993 & & & \\
\hline & $\begin{array}{l}\text { Menu and } \\
\text { Categories }\end{array}$ & 192 & 29,94 & 958 & \multirow[t]{2}{*}{430} & \multirow[t]{2}{*}{$-1,2$} & \multirow[t]{2}{*}{0,25} \\
\hline & Search & & 35,06 & 1122 & & & \\
\hline & Advertisement & & 29,59 & 947 & \multirow{2}{*}{419} & \multirow{2}{*}{$-1,3$} & \multirow{2}{*}{0,18} \\
\hline & Search & & 35,41 & 1133 & & & \\
\hline \multirow{6}{*}{ LowGama } & $\begin{array}{l}\text { Menu and } \\
\text { Categories }\end{array}$ & & 32,55 & 1041,5 & \multirow[t]{2}{*}{510,5} & \multirow[t]{2}{*}{$-0,02$} & \multirow[t]{2}{*}{0,98} \\
\hline & Advertisement & & 32,45 & 1038,5 & & & \\
\hline & $\begin{array}{l}\text { Menu and } \\
\text { Categories }\end{array}$ & 192 & 32,19 & 1030 & \multirow[t]{2}{*}{502} & \multirow[t]{2}{*}{$-0,13$} & \multirow[t]{2}{*}{0,89} \\
\hline & Search & & 32,81 & 1050 & & & \\
\hline & Advertisement & & 32,47 & 1039 & \multirow{2}{*}{511} & \multirow{2}{*}{$-0,01$} & \multirow{2}{*}{0,99} \\
\hline & Search & & 32,53 & 1041 & & & \\
\hline \multirow{6}{*}{ FACS } & $\begin{array}{l}\text { Menu and } \\
\text { Categories }\end{array}$ & & 30,26 & 938 & \multirow[t]{2}{*}{442} & \multirow[t]{2}{*}{$-0,5$} & 0,59 \\
\hline & Advertisement & & 32,74 & 1015 & & & \\
\hline & $\begin{array}{l}\text { Menu and } \\
\text { Categories }\end{array}$ & 186 & 29,29 & 908 & 412 & $-0,9$ & 0,33 \\
\hline & Search & & 33,71 & 1045 & & & \\
\hline & Advertisement & & 30,5 & 945,5 & 4495 & -0.4 & 0.66 \\
\hline & Search & & 32,5 & 1007,5 & & & \\
\hline
\end{tabular}


When Table 7 is examined, according to the Mann Whitney $U$ test results at the 95\% confidence interval $[(\mathrm{U})=318, \mathrm{p}<0.05]$, there is a statistically significant difference between the mean rank of LowBeta of the "Advertisement" design element (26.44) and the mean rank of LowBeta of the "Search" design element (38.56). On the other hand, when the confidence interval is decreased to $90 \%$, a significant difference [ $(\mathrm{U}=389.5), \mathrm{p}<0.1]$ between the mean rank of LowBeta of the "Menu and categories" design element (28.67) and the mean rank of LowBeta data of the "Search" design element (36.33). When the mean rank scores are compared, it is understood that "Search" design element score is higher. In other words, this result can be interpreted as the "Search" design element in LowBeta data type causes more emotional changes than other elements. In addition, there is no statistically significant difference between the mean rank of other data types related to the design elements ( $p>0.1, p>0.05)$.

\section{Discussion and Conclusion}

This study investigated whether there was a change in the emotions of the users when they focused on the "menu and categories", "advertisement" and "search" design components on e-commerce pages or not. Users' emotions changes were examined in terms of pulse, EEG, skin conductivity and facial expressions which were obtained with a user experience study. Users' focus on design components were followed with eye tracking method. Total 32 participants took part in the study, who were selected with purposive sampling method. It was concluded that there were some differences in the emotion changes of the participants in the "menu and categories", "advertisement" and "search" design component.

When pulse changes of the participants were examined, it was observed that there was a significant emotion change between the "menu and categories" design element and the "advertisement" and "search" design elements. Pulse changes of the participants who focused on "advertisement" design element were higher than those who focus on "menu and categories" design element. People's pulse could change depending on stress, as well as depending on excitement. Therefore, to understand the reason of its change, it is necessary to examine GSR, EEG and facial expressions data (Çakar et al., 2017). However, no significant difference was found in the participants' GSR, EEG and facial expressions in terms of these two design components.

On the other hand, the study revealed that the change in pulse when the participants focused on the "search" design element was higher than the "menu and categories" design element. In order to support this result, findings in EEG, GSR or facial expressions were used. Although there is no difference in terms of facial expression and GSR, it can be concluded the participants were highly concentrated when focusing on the "search" design component since LowBeta value was significantly higher at the $90 \%$ confidence interval for the "search" design component.

When EEG data was analyzed and interpreted, significant differences were found only for LowBeta wave. When the LowBeta is compared for "advertisement" and "search" components, it was found that LowBeta value is significantly higher for the those who were focusing on the "search" design component. Accordingly, it was understood that the active concentrations of the participants were high when they focused on the "search" component (Yadava et al., 2017; Çakar et al., 2017). When the GSR and facial expressions data were analyzed, no significant difference was observed in user emotions in the processes of focusing on the "menu and categories", "advertisement" and "search" design components.

It has been interpreted that the "search" design element causes more emotion changes than other elements in the LowBeta data type, which gives information from EEG waves, especially in terms of active concentration. This result implies that "Search" design component should be added to menu, simple appearance, text, site color and accessibility factors, which were found as the elements to be paid more attention by Coşkun and Yücel (2021) by using EEG method. Similarly, in the study of Çakar et al. (2017), it was stated that the "search" design component is among the components that cause discomfort for users. 
To sum up, this study aims to examine the changes in emotions of the users when they focus on three important design components for ecommerce websites, the "menu and categories", "advertisement" and "search", by using EEG, GSR, pulse, facial expressions and to present realistic and consistent results as suggested by Yadava et al. (2017). Generally, it could be concluded that the "search" design component caused higher active concentration in the participants compared to the other components, on the other hand, the pulse change of the participants who focused on the "advertisement" design component was high. However, in the scope of the study, sufficient findings could not be reached in terms of explaining the reasons for these differences.

Contrary to the statement of Dospinescu and Parcă-Robu (2017), additional data is needed to determine the efficiency and effectiveness of components that are found to have high interaction with eye tracking device. In this study, it is suggested to examine the reasons of emotional changes caused by interaction, in other words intense focus, with design components a new research problem.

\section{References}

Balat, S.., Kayalı, B., Gündüz, A., \& Göktaş, Y. (2019). Doktora tezlerinde alınan geçerlik ve güvenirlik önlemleri. The 28th International Conference on Educational Sciences, (s.51-69). Ankara.

Baş, T., \& Tüzün, H. (2014). Tüketicileri (Kullanıcıları) ve ürün kullanımlarını analiz etmek için göz izleme yönteminin kullanılması. In E. B. Müberra Babaoğul, \& A. Şener (Dü), Tüketici Yazıları (IV) (p.217-234). Ankara: Eryılmaz Ofset.

Başaran, S. (2014). E-ticaret Uygulamalarında Kullanıcı Deneyimi. (Unpublished master's thesis). Arel University, Institute of Social Sciences, İstanbul.

Brinberg, D., \& McGrath, J. E. (1985). Validity and the research process. Beverly Hills, CA: SAGE Publications, Incorporated.

Büyüköztürk, Ş., Kılıç Çakmak, E., Akgün, Ö. E., Karadeniz, Ş., \& Demirel, F. (2014). Bilimsel Araştırma Yöntemleri (p.1-36). Ankara: Pegem Akademi.
Clarke, B. D., \& Hattingh, M. J. (2020, November). Impact that Website Design Elements on the Users of e-Commerce Websites. 2020 2nd International Multidisciplinary Information Technology and Engineering Conference (IMITEC) (p.1-7). IEEE.

Coşkun, P., \& Yücel, A. (2021). EEG Yöntemi ile tüketicilerin elektronik ticaret sitelerine yönelik algıları üzerine deneysel bir çalışma. Süleyman Demirel Üniversitesi Vizyoner Dergisi, 12(29), 286-298.

Coşkun Karadağ, N. (2005). Elektronik ticarette vergilendirme sorunları ve uluslar arası düzeyde çözüm arayışlarının Türkiye açısından değerlendirilmesi. Çukurova Üniversitesi Sosyal Bilimler Enstitüsü Dergisi, 14(1), 153-169.

Çakar, T., Rızvanoğlu, K., Öztürk, Ö., Çelik, D. Z., \& Gürvardar, İ. (2017). The use of neurometric and biometric research methods in understanding the user experience during product search of first-time buyers in Ecommerce. International Conference of Design, User Experience and Usability (p.342-362). içinde Springer.

Destari, F., Indraningrat, K., \& Putri, M. N. N. (2020). Impact of shopping emotion towards impulse buying in E-commerce platform. Jurnal Manajemen dan Pemasaran Jasa, 13(1), 47-64.

Dospinescu, O., Percă-Robu, AE. (2017). The analysis of e-commerce sites with eye-tracking technologies. BRAIN: Broad Research in Artificial Intelligence and Neuroscience, 8(3), 85100.

Erbaşlar, G., \& Dokur, Ş. (2008). Elektronik ticaret. Ankara: Nobel Yayın Dağıtım.

Erserim, G. (2019). Kuşaklar arasında e-ticaret'e yönelik tutum farkliliklarının değerlendirilmesi (Published master's thesis). Bahçeşehir University, Institute of Social Sciences, İstanbul.

Farnsworth, B. (2019). Facial Action Coding System (FACS) - A visual guidebook. Retrieved February 10, 2021 from https://imotions.com/blog/facial-action-codingsystem/

Grimnes, S. (1982). Psychogalvanic reflex and changes in electrical parameters of dry skin. 
Medical and Biological Engineering and Computing, 20(6), 734-740.

Guo, F., Cao, Y., Ding, Y., Liu, W., \& Zhang, X. (2015). A multimodal measurement method of users' emotional experiences shopping online. Human Factors and Ergonomics in Manufacturing \& Service Industries, 25(5), 585598.

Hassenzahl, M. \& Tractinsky, N. (2006). User experience - a research Agenda. Behaviour $\mathcal{E}$ Information Technology, 25(2), 91-97. https://doi.org/10.1080/01449290500330331

Jewells, T. J., \& Timbrell, G. T. (2001). Towards a Definition of B2C \& B2B E-commerce. Proceedings of the Twelfth Australasian Conference on Information Systems ACIS 2001 Proceedings, 56.

Kalaycı, Ş. (2014). SPSS uygulamalı çok değişkenli istatistik teknikleri (6th ed.). Ankara: Asil Yayın Dağıtım

Koufaris, M. (2002). Applying the technology acceptance model and flow theory to online consumer behavior. Information Systems Research, 13(2), 205-223.

Lancaster, G. A., Dodd, S., \& Williamson, P. R. (2004). Design and analysis of pilot studies: Recommendations for good practice. Journal of Evaluation in Clinical Practice, 10(2), 307-312.

Laudon, K. C., \& Traver, G. (2011). E-commerce. England: Pearson/Addison Wesley.

Lohse, G. L., \& Spiller, P. (1998). Electronic Shopping. Communications of the ACM, 41(7), 81-87.

McMillan, J. H., \& Schumacher, S. (2010). Research in education: evidence-based inquiry. Perarson: MyEducationLab Series.

Medikal Akademi. (2021). Nabız nedir, nasıl ölçülür? Normal hızı kaçtır? Nasıl düşürülür?. Nisan 10, 2021 tarihinde https://www.medikalakademi.com.tr/ adresinden alınd $\imath$

Merriam, S. B. (1998). Qualitative Research and Case Study Applications in Education. Revised and Expanded from "Case Study Research in Education.". Jossey-Bass Publishers, 350 Sansome St, San Francisco, CA 94104.

Nakatani, C., \& Pollatsek, A. (2004). An eye movement analysis of "Mental Rotation" of simple scenes. Perception $\mathcal{E}$ Psychophysics, 66(7), 1227-1245.
Nielsen, J. (1993). Usability engineering. Cambridge MA: Academic Press.

Nielsen, J. (2002). Top ten guidelines for homepage usability. Mart 20, 2021 tarihinde https://www.nngroup.com/articles/top-tenguidelines-for-homepage-usability/ adresinden alind 1

Nissen, M. E. (1997). The commerce model for electronic redesign. Journal of Internet Purchasing, 1(2), 9702-01.

Oliveira, R. P., Afonso, A. P., \& Pinto, A. S. (2020). ECommerce website accessibility evaluation: case study in Portugal. Şubat 10, 2021 tarihinde

https://www.researchgate.net/profile/Ana-

Afonso-4/publication/347521148_E-

Commerce_Website_Accessibility_Evaluation_C ase_Study_in_Portugal/links/5ff1eb68299bf1408 8694ac4/E-Commerce-Website-AccessibilityEvaluation-Case-Study-in-Portugal.pdf adresinden alınd 1

Özmen, E., Karaman, E., \& Alkış, N. (2021). E-ticaret web sayfalarında tasarım bileşenlerinin göz izleme yöntemiyle değerlendirilmesi. 8 . Internatioal Management Information Systems Conference, (p.36), İstanbul.

Ritonummi, S. (2020). User experience on an ecommerce website: A case study. (Master's thesis) Jyväskylä University, Finland.

Sadedil, S. N., \& Uraltaş, K. N. (2018). Nörobilim araştırmalarında kullanılan görüntüleme yöntemlerinin nöropazarlama alanında kullanılmasına yönelik kavramsal bir çalışma. Sosyal Bilimler Dergisi / TheJournal of SocialScience, 5(20), 257-277.

Safavi, R. (2009, November). Interface design issues to enhance usability of e-commerce websites and aystems. In 2009 International Conference on Computer Technology and Development, IEEE.

Tayfun, N. Ö., \& Öçlü, B. (2015). Yeşil pazarlama uygulamasının tüketiciler açısından algılanmasının nöropazarlama tekniği ile araştırılması. Uludă̆ Üniversitesi İktisadi ve İdari Bilimler Fakültesi Dergisi, 34(2), 95-113.

Topu, F. B., Baydaş, Ö., Turan, Z., \& Göktaş, Y. (2013). Common reliability and validity strategies in instructional technology research. Çukurova Üniversitesi Ĕ̆itim Fakültesi Dergisi, 42(1), 110126. 
Albert, B., \& Tullis, T. (2013). Measuring the user experience: collecting, analyzing, and presenting usability metrics. Newnes.

Wong W., Bartels M., Chrobot N. (2014) Practical eye tracking of the ecommerce website user experience. In: Stephanidis C., Antona M. (eds) Universal Access in Human-Computer Interaction. Design for All and Accessibility Practice. UAHCI 2014. Lecture Notes in Computer Science, vol 8516. Springer, Cham. https://doi.org/10.1007/978-3-319-07509-9 11

Yadava, M., Kumar, P., Saini, R., Roy, P. P., \& Dogra, D. P. (2017). Analysis of EEG signals and its application to neuromarketing. Multimedia Tools and Applications, 76(18), 19087-19111. 